\title{
Author Correction: Do rogue antibodies make the difference between mild versus severe COVID-19?
}

\section{Alexandra Flemming}

Correction to: Nature Reviews Immunology https://doi.org/10.1038/s41577-021-00511-4, published online 04 February 2021.

The original version of this In Brief stated that patients with severe COVID-19 produced "virus-specific antibodies that appeared to functionally block the production of ISG-expressing cells...". However, this is not correct; the original publication reported that these antibodies had a very broad pattern of self-reactivity. Therefore, the term "virus-specific" has been removed.

https://doi.org/10.1038/s41577-021-00520-3 I Published online 18 February 2021

(c) Springer Nature Limited 2021 